\title{
I.С. Івченко. Розвиток дендрології у XVIII-XX ст. - К.: НПУ ім. М.П. Драгоманова, 2009. - 287 с. І.С. Івченко. Історичне формування дендрології. К.: Вид-во НПУ імені М.П. Драгоманова, 20011. - 351 с.
}

Нині серед величезного масиву наукової та науково-популярної ботанічної літератури недостатньо видань, присвячених узагальненню та переосмисленню результатів вивчення ботанічних об’єктів за достатньо тривалий період. Рецензовані монографії є прикладом такого узагальнення щодо розвитку дендрологічної науки. Вони написані відомим фахівцем у галузі дендрології доцентом Національного педагогічного університету ім. М.П. Драгоманова, кандидатом біологічних наук I.C. Івченком. Перша книга "Розвиток дендрології у XVIII-XX ст." вийшла у світ у 2009 році, де висвітлена історія дендрології в Україні в контексті розвитку ботаніки впродовж XVIII-XX століть, вперше розглянуто розвиток етноботанічного напрямку в дендролоргії, особливості розвитку в ній на засадах теорії фітонізму морфологогеографічної концепції і становлення ейдолого-таксономічного напрямку. Книга може бути використана фахівцями у галузі інтродукції, ресурсології, аутфітосозології, зеленому будівництві, створенні арборетумів використана у лекційній роботі. Робота рекомендована до друку Вченою Радою Національного педагогічного університету ім. М.П. Драгоманова. Книга складається із вступу, семи розділів, списку використаних джерел.

Книгу відкриває короткий “Вступ”, у якому розкривається мета дослідження та розглядається значення дендрології в контексті проведених вітчизняних та міжнародних форумів. У розділі I “Історіографія проблеми і джерельна база досліджень” автор простежує історію становлення дендрології від праць Геродота до наших днів. Він приходить до висновку, що дендрологічні праці розкривають актуальні питання первинного i подальшого розвитку різноманітних флористичних, систематичних, ресурсознавчих, біоморфологічних складових науки про деревні рослини. При цьому наголошується на тому, що в біолого-ботанічному контексті формування визначальних наукових здобутків має доповнюватися історичними, етнографічно-етнологічними, літературознавчими, культурологічними джерелами. Автор зазначає, що провідну роль в історичному дослідженні відіграють ситуативні, ексклюзивні характеристики діяльності відповідних осіб у процесі пізнання дендрологічних об'єктів.

Розділ II “Формування і розвиток науки про деревні рослини в країнах світу” $\epsilon$ логічним продовженням попереднього. Автор відзначає, що одним з головних чинників розвитку дендрологічної систематики і флористики ліннеївської і дарвінівської епох $\epsilon$ пізнання дендрологічних об'єктів в етноботанічному аспекті, що розуміється як поєднання різних напрямків ботаніки, насамперед ресурсологічного та істориконаукового. Детально розглядається діяльність К. Ліннея та його послідовників у становленні дендрології, основним здобутком яких було впровадження бінарної номенклатури простого і зручного засобу для опрацювання різноманітних властивостей деревних рослин. Важливим, суттєвим чинником відтоді стають точність при визначенні низки географічних осередків, а укладені на єдиній основі дані підлягали натурфілософському осмисленню, що домінувало в ліннеївську епоху.

Розділ III “Укладання основ дендрологічної методології та їх розвиток в сучасну епоху" присвячений розгляду пріоритетних методичних розробок в дендрології, які $\epsilon$ загальновизнаними в біологічній сфері в історичному аспекті, а також висвітлення 
тенденцій факторів виникнення в науковій літературі ідеологічного апарату, найперших експериментальних праць, первинні етапи їх розвитку, авторське бачення наміченої проблеми і власний внесок у методологію даної науки.

IV розділ "Вітчизняна дендрологія XIX ст. і передумови її подальшого розвитку” присвячений доробку українських учених в галузі дендрологічної науки у XIX-XX століттях. Автор зазначає, що в названий період основні відомості про нові види які поповнювали дендрофлористичний реєстр України, надходили, здебільшого, із Західної Європи, в країнах якої особливо активно відбувалося флористичне, рідше таксономічне обстеження низки регіонів і груп. У розділі резонно зазначається і те, що для пізнання дендрологічних об'єктів України необхідний розгляд історичної трансформації теорії анафіта, як об'єднувальної парадигми сучасного тлумачення теорії фітонізма. Урахування поглядів фітоністів-дендрологів дозволить розглянути еволюцію подовження стеблових частин деревних рослин, їх послідовно зростаючу спеціалізацію, зміцнення стебел унаслідок лігніфікації й підвищення камбіальної активності тощо.

У розділі V “Диференціація дендрологічних напрямків у XIX ст. - першій половині XX ст.” висвітлені лінгвістичні аспекти щодо формування та розвитку етимології низки природознавчих термінів, питання етнодендрологічного районування та розвитку морфолого-географічної концепції, історичної послідовності диференціації провідних наукових напрямків в дендрології.

Розділ VI “Історія досліджень корисних властивостей деревних рослин України” присвячений питанням прикладних сфер ботаніки і дендрології, які пов'язані 3 вивченням корисних для людини рослин.

Розділ VII "Історико-ситемний підхід в дендрології та його розвиток в XX ст." присвячений розгляду історико-системного підходу в дендрології та його розвитку в $\mathrm{XX}$ столітті, що дозволило автору сформувати комплексний підхід для загального аналізу визначальних епох природознавства класифікаційних досліджень 3 періодами утилітарної, штучної і еволюційної систематизації рослинних об’єктів.

Завершується книга 12 висновками, які $\epsilon$ аргументованими $і$ повністю відображають ії зміст.

Друга книга "Історичне формування дендрології опублікована у 2011 році $\epsilon$ продовженням попередньої праці і присвячена історії формування науки про деревні рослини. Книга складається із вступу, чотирьох розділів та списку використаних джерел. У короткому “Вступі" наголошується на доцільності досліджень 3 історії формування дендрології. У розділі I “Формування дендрологічних класифікацій в контексті розвитку науки і техніки” чільне місце відводиться історичним особам, які, на переконання автора, відіграли важливу роль у становленні дендрології та розвитку дендрологічних класифікацій.

Розділ II "Морфогенетичні властивості корисних деревних рослин та історія їх колекцій” присвячений висвітленню історії створення арборетумів та ролі вчених у їх організації, науковому їх обгрунтуванні тощо. Автор розглядає корисні властивості низки деревних рослин та наводить імена дослідників, що вивчали ці властивості, знайомить з історією створення в Україні низки відомих нині дендропарків (“Софіївка”, “Олександрія" та ін.) та колекційними дослідженнями дедрофлори.

Розділ III "Класичні, експериментальні і прикладні дослідження біоморф деревних рослин" починається із висвітлення біометричних показників низки екзотичних деревних рослин, їх значенні для людини. Автор зупиняється на ще маловідомому для читачів факті формування лісових шкіл та їх зачинателів, на розвитку лісогосподарської освіти та підготовці лісогосподарських кадрів 3 характеристикою видатних вчителів-лісознавців.

У заключному четвертому розділі “Історичне формування фітобіологічної концепції в дендрології” автор знайомить читача 3 етнолого-етноботанічним 
напрямком у вітчизняній дендрології та історією його започаткування. Формування i зміцнення духовно-культурного розділу етноботаніки він знаходить як підтвердження y релігійних i адміністративних спорудах XVII-XIX століття та подає їх характеристику. Наголошується на тому, що в етноботанічному контексті відзначені спроби встановити магічні властивості дерев і кущів. Висвітлюються питання біогеографії із зазначенням визначних iï представників, у працях яких знайшло своє відображення поширення видів дендрофлори; мистецький та літературний напрямки етноботаніки.

Обидві книги написані в одному ключі і стилі, тому мають подібні неточності. Не торкаючись дрібниць, зауважимо таке. Зміст розділів книг автор подає значно ширше, ніж це зазначено у їх назві, часто з ліричними відступами, які мало торкаються мети розділу. Це, при збільшенні різнобічної інформації, розмиває головну ідею висвітлення розділу і не сприяє сприйняттю його змісту. Поряд з цим, у деяких розділах основні моменти, що зазначені у його назві, розкриті слабо. Наприклад, у третьому розділі першої книги, присвяченому укладанню основ дендрологічної методології, питанням останньої приділено мало уваги. Для кращого сприйняття змісту книг, досить великі за обсягом розділи варто було б поділити на підрозділи. Невдалими у обох книгах є представлений ілюстративний матеріал — фотографії чорно-білі, темні, дуже дрібні, а тому мало інформативні. Назви рисунків часто не відповідають представленому змісту. Наприклад, у другій книзі на сторінці 29 рисунок 7 ,що має назву “Природознавці Центральної і Східної Свропи в контексті історичного формування дендрології у XIX-XX ст.”, розміщено поряд з фотографіями вчених невідомо для чого і фото гербарного зразка Euonymus suberosa? Вважаємо також, що назва другої книги вибрана невдало. Ще одним недоліком цих видань $\epsilon$ те що їх тексти рясніють помилками.

Вважаємо, що висловлені нами зауваження не применшують значущості рецензованих книг і можуть бути враховані при підготовці наступних видань. Загальна оцінка рецензованих монографій висока, це явище в ботанічній історіографії. Автор використав для їх підготовки дуже велику кількість літературних джерел, що дасть можливість читачу побачити цілісну картину історії формування науки про деревні рослини - дендрології. 